\title{
POTENCIAL GEOTURÍSTICO DE QUEDAS D'ÁGUA DO ESTADO DE MINAS GERAIS, BRASIL ${ }^{1}$
}

\author{
GEOTURISTIC POTENTIAL OF WATERFALLS IN THE STATE OF MINAS GERAIS, \\ BRAZIL
}

\author{
Lilian Carla Moreira Bento \\ Doutora em Geografia, Docente do Programa de Graduação e Pós-graduação em Geografia da \\ Universidade Federal de Uberlândia, Campus de Ituiutaba, Minas Gerais, Brasil \\ liliancmb@ufu.br
}

Recebido: 09.12.2021

Aceito: 08.02.2022

\begin{abstract}
Resumo
Este trabalho busca refletir sobre alguns conceitos básicos como geoturismo e a diferença entre produto e potencial turístico, de forma a subsidiar o objetivo central que é analisar o potencial geoturístico de quedas d'água, acrescentando um novo valor (científico) e uso (educativo) às quedas de unidades de conservação. Em função do número elevado de áreas protegidas e diversidade geológica encontradas no estado, se restringiu a três unidades (Refúgio de Vida Silvestre Estadual dos Rios Tijuco e da Prata, Parque Estadual do Ibitipoca (PEI) e Parque Nacional Serra da Canastra - PARNA Serra da Canastra). Compreende uma pesquisa qualitativa e espera-se que os resultados possam preencher uma lacuna do ponto de vista do entendimento das quedas d'água e sua correlação com as unidades morfoestruturais, servindo aos gestores das unidades de conservação como promoção aos programas de educação e interpretação ambiental, um dos pilares do geoturismo.
\end{abstract}

Palavras-chave: geodiversidade, turismo, valor didático.

\begin{abstract}
This work seeks to reflect on some basic concepts such as geotourism and the difference between the product and tourist potential, to support the main objective, which is to analyze the geotouristic potential of waterfalls, adding a new (scientific) and (educational) use to the falls of conservation units. Due to the high number of protected areas and geological diversity found in the state, this work was restricted to three units (Rivers Tijuco and Prata State Wildlife Refuge, Ibitipoca State Park (PEI) and Serra da Canastra National Park PARNA Serra da Canasta). It comprises qualitative research, and it is expected that the results can fill a gap in understanding waterfalls and their correlation with morphostructural units, being useful to conservation unit managers as a promotion of education programs and environmental interpretation, one of the pillars of geotourism.
\end{abstract}

Keywords: geodiversity, tourism, educational value.

\footnotetext{
${ }^{1}$ Artigo baseado na palestra da autora no $19^{\circ}$ SEMINÁRIO CLÁUDIO PERES DE PRÁTICAS DE ENSINO E GEOGRAFIA APLICADA - GEOPATRIMÔNIO: CONEXÕES INTERDISCIPLINARES, da PUC Minas
} 


\section{INTRODUÇÃO}

O Brasil é detentor de uma considerável extensão de terras, contando com uma grande variedade e relevante biodiversidade e geodiversidade (Figura 1). Esta última refere-se, em linhas gerais, a todos os elementos naturais de base abiótica, bem como aos processos, pretéritos e atuais, que os deram origem, tais como os minerais, rochas, solo, relevo, fósseis, entre outros (BRILHA, 2005; GRAY, 2005; NASCIMENTO, RUCHKYS E MANTESSO NETO, 2008).

O Estado de Minas Gerais não foge à regra, e é testemunha de uma extensa história geológica que vai do Proterozoico até o Cenozoico; resultando em elevada diversidade litológica, a qual, aliada à diversidade de relevo e solos acaba favorecendo a adaptação de animais e plantas, levando a uma alta biodiversidade, além de locais de grande beleza, como as quedas d'água, muitas das quais coincidentes com as áreas das unidades de conservação (SILVA et al., 2021).

\section{A GEODIVERSIDADE NAGIONAL}

As 36 áreas se destacam pela variedade de rochas, formas de relevo e solos

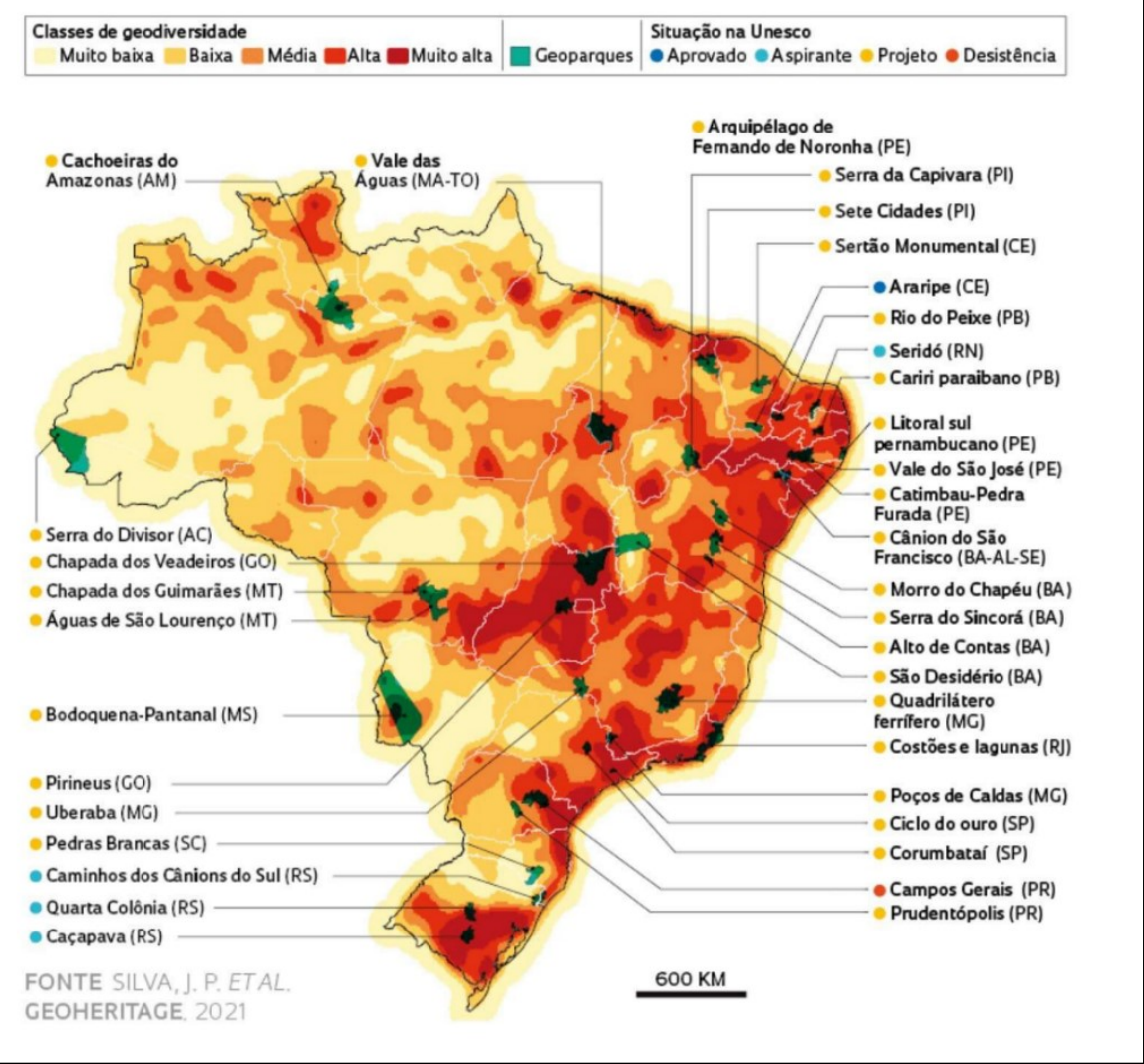

Figura 1 - Geodiversidade nacional

Fonte: Fioravanti, 2021. 
O objetivo desse estudo foi analisar o potencial geoturístico de quedas d'água, de forma a subsidiar a inserção de um novo valor (científico) e uso (educativo) de três quedas localizadas nas respectivas unidades de conservação do estado de Minas Gerais, Refúgio de Vida Silvestre Estadual dos Rios Tijuco e da Prata, Parque Estadual do Ibitipoca (PEI) e Parque Nacional Serra da Canastra - PARNA Serra da Canastra, cada uma delas localizadas em unidades morfoestruturais distintas.

A justificativa é que se tratam de áreas com grande visitação, principalmente, por conta da beleza cênica e possibilidade de realização de atividades recreativas relacionadas às suas quedas d'água, mas que não contam, ainda, com programas efetivos de educação e/ou interpretação ambientais voltados ao seu entendimento, os quais são fundamentais para o processo de valorização do patrimônio natural e um dos pilares do geoturismo.

Por ser tratar de uma pesquisa qualitativa, o principal procedimento metodológico empregado foi trabalho de gabinete para realizar o inventário bibliográfico. O levantamento ocorreu em sites como ResearchGate, Scielo, Portal da Capes, Biblioteca Digital Brasileira de Teses e Dissertações (BDTD), Redalyc, Google acadêmico. Pertinente destacar que essas unidades foram alvo de estudo em pesquisas pretéritas, as quais possibilitaram obter dados primários sobre as quedas d'água, bem como selecionar uma de cada unidade para contextualizar a análise em questão (Figura 2). 


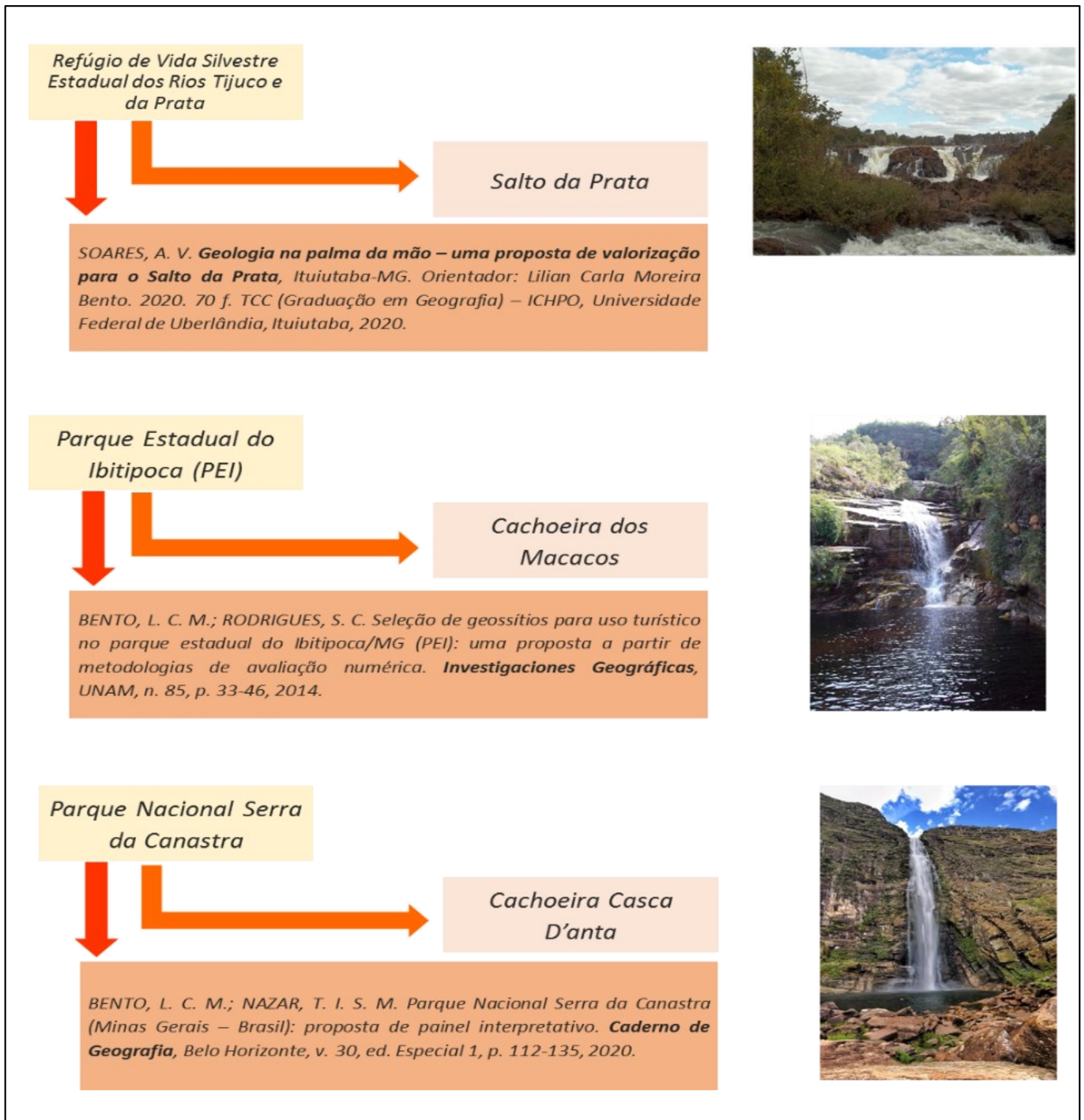

Figura 2 - Fluxograma ilustrado com as quedas selecionadas de cada unidade de conservação trabalhada e principais fontes utilizadas

Autoria: Bento, 2021.

\section{RESULTADOS E DISCUSSÃO}

\subsection{Geoturismo, o que é?}

Geoturismo é um termo que tem recebido bastante atenção no meio acadêmico (RUCHKYS; MANSUR; BENTO, 2017), ocorrendo um avanço no sentido de concebê-lo como um novo segmento turístico, ao invés de subsegmento do ecoturismo, como foi inicialmente tratado (BENTO; FARIAS; NASCIMENTO, 2020; COUTINHO et al., 2019; SILVA et al., 2021). 
Algumas especificidades ou particularidades do geoturismo são relevantes de serem sumarizadas, a saber: $i$ - o prefixo geo não engloba apenas os atrativos geológicos, mas sim, o geopatrimônio de modo geral; ii- esse geopatrimônio não precisa ser apenas de áreas naturais, geossítios urbanos também podem (e devem) ser aproveitados; iii- a interpretação ambiental, seja por meios personalizados ou não, precisa acontecer para que se consiga a valorização e divulgação dessa vertente abiótica do meio ambiente, um dos objetivos do geoturismo para se alcançar a geoconservação (BENTO, 2014).

Há uma diferenciação de segmento de um mero atrativo turístico, no sentido de que é uma classificação realizada com a partir de inventários de oferta e demanda, ou seja, há todo um suporte criado para atender à atividade turística por meio de um produto. Este precisa ter um ou mais atrativos, independentemente do tipo; mas nem todo atrativo pode ser considerado um produto. Isso ocorre, pois, de modo genérico, um produto significa "aquilo que é produzido para venda no mercado" (Dicionário online) e, para isso, precisa estar em condições de comercialização. Do ponto de vista da atividade turística, um produto é quando o atrativo suporta a visitação, contando com serviços, infraestrutura de alojamento e alimentação, acesso, entre outros, criados especialmente para os visitantes e/ou turistas (COUTINHO et al., 2019).

A segmentação é, portanto, uma estratégia de mercado voltada a grupos específicos, uma vez que oferece produtos com base nas necessidades identificadas (COUTINHO et al., 2019). Dentro desse contexto, pode-se afirmar que a concepção do geoturismo como segmento turístico, fugindo das discussões meramente acadêmicas, está atrelada a existência de uma oferta e demanda de produtos formatados e comercializados (SILVA et al., 2021).

No trabalho, "Geoturismo, um novo segmento turístico?", Bento, Farias e Nascimento (2020), argumentam que não existe no Brasil, até o momento, um diagnóstico que comprove a existência de geoturistas, isto é, demanda por um produto geoturístico; muito menos um inventário do geopatrimônio nacional. No caso deste último, o que não faltam são trabalhos acadêmicos e de algumas instituições, como o Serviço Geológico do Brasil (CPRM), que vêm tentando fazer um esboço da geodiversidade, destacando índices e o potencial do geoturismo, assim como mapeamentos.

Entretanto, há de se reconhecer um tímido avanço na criação de roteiros especializados e que já têm o geopatrimônio como atrativo principal, sinalizando para uma mudança de paradigma, com a valorização e divulgação da temática, com possíveis impactos positivos no que se refere ao processo de geoconservação. Esse é o caso do 
roteiro em destaque a seguir (Figura 3), elaborado em específico para a visitação no Geoparque (aspirante) Seridó. E o Ministério do Turismo também vem caminhando nesse sentindo, dando mais atenção à temática dos geoparques, inclusive, está em desenvolvimento o Manual de desenvolvimento de projetos turísticos de geoparques (FACURI, 20212).
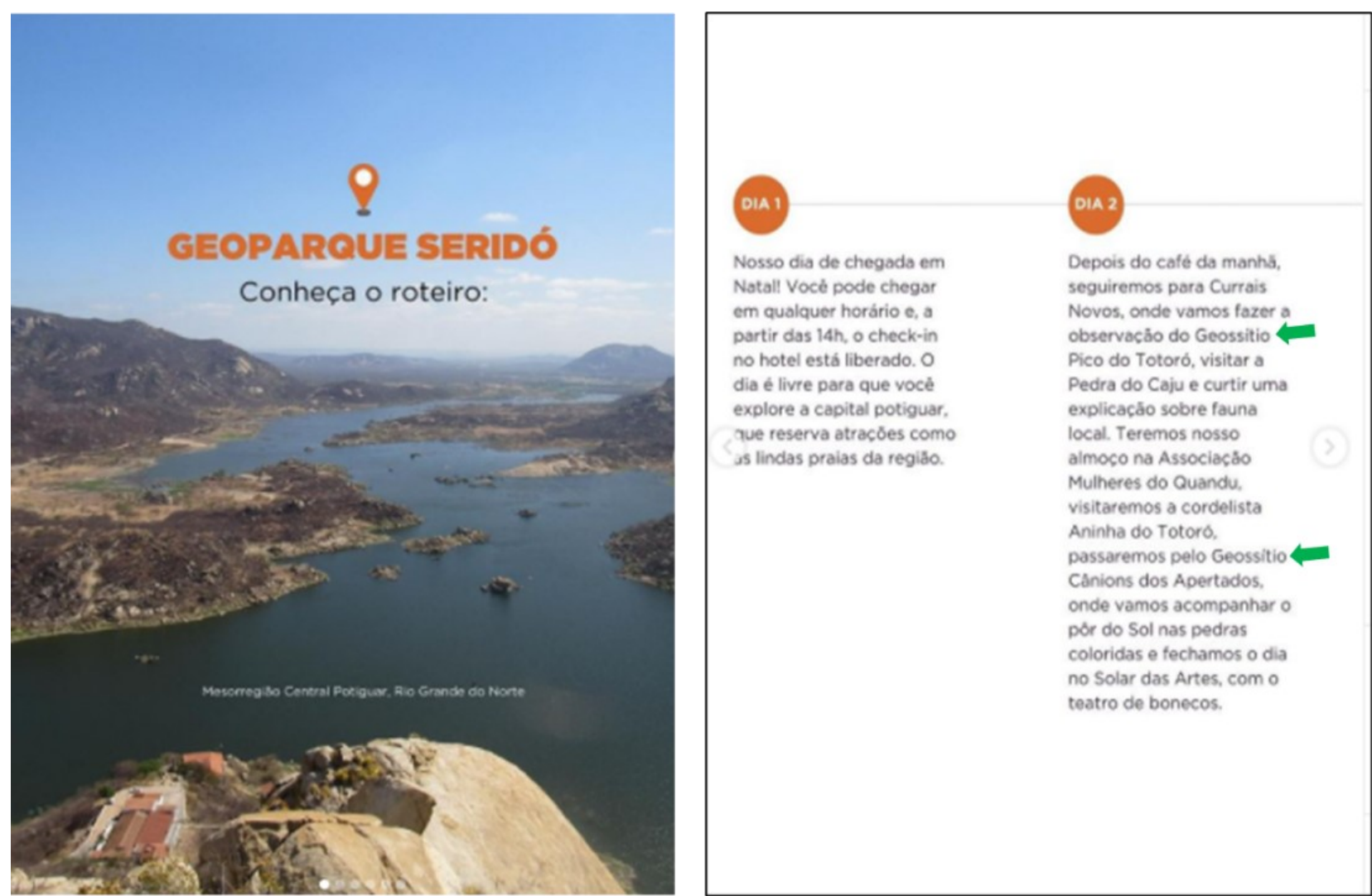

Figura 3 - Extrato de roteiro retirado do Instagram com destaque para os geossítios a serem visitados no Geoparque (aspirante) Seridó, sinalizando para o início da formatação e comercialização de produtos geoturísticos no Brasil

Autoria: Bento, 2021.

Do ponto de vista do geoturismo, Dowling (2011) corrobora com esse entendimento ao associá-lo a três sistemas interligados, dois formados pelos atrativos que podem ser tanto as formas (elementos da geodiversidade) como os processos a elas relacionados e, principalmente, toda a infraestrutura que dá suporte à atividade turística (Figura 4). Inclusive, sendo o entendimento dos locais visitados um dos diferenciais do geoturismo, a existência de meios interpretativos é condição fundamental na concepção de produtos geoturísticos, sendo considerada por Reynard (2008), como oferta geoturística derivada.

\footnotetext{
2 Trecho da palestra de Nicole Facuri, "O Ministério do Turismo e os geoparques", apresentada no III Workshop do Geoparque Chapada dos Guimarães, em Cuiabá, no dia 29 de novembro de 2021.
} 


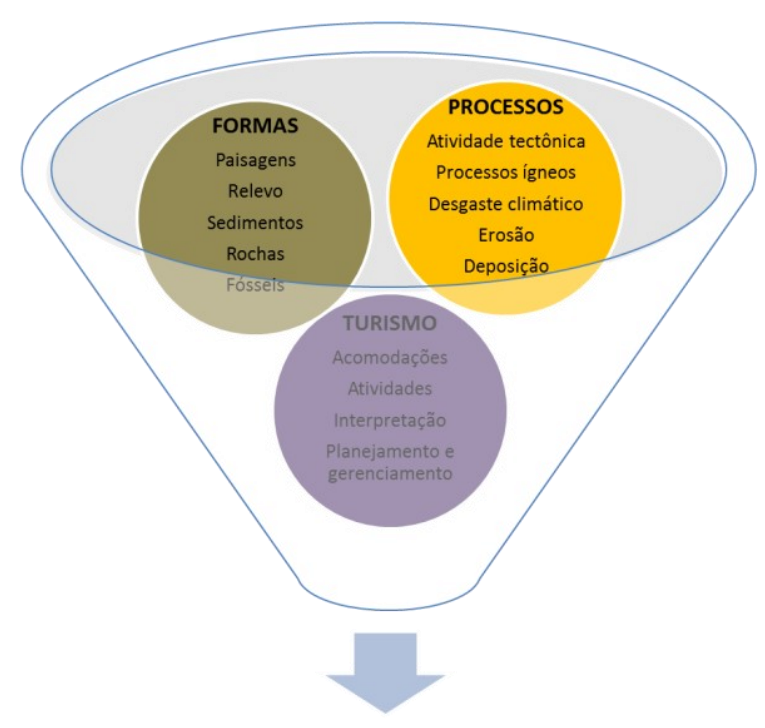

\section{GEOTURISMO}

Figura 4 - Subsistemas do Geoturismo

Autoria: Adaptado de Dowling, 2011.

O debate se o geoturismo é segmento, subsegmento, prática turística, entre outros, é apenas uma tentativa de setorizá-lo ou classifica-lo, exercício comum no seio da ciência de modo geral. O fato é que é uma prática antiga (COUTINHO et al., 2019), mas um conceito relativamente recente e, como tal, em construção e recebendo contribuições e adequações temporais, espaciais e pessoais. Emergiu como uma necessidade de se dar visibilidade e proteção a geodiversidade e, como tal, seu debate ainda se faz pertinente e sua implantação, dentro das premissas do planejamento e sustentabilidade, pode vir a ser uma ferramenta para a geoconservação.

\subsection{Quedas d'água e sua importância}

Quedas d'água podem ser consideradas como uma categoria do geopatrimônio, hidrossítios, sendo um termo genérico para designar rupturas de declive no perfil longitudinal de um curso d'água. Elas podem ser analisadas do ponto de vista de sua classificação e/ou gênese.

No primeiro caso, se consideram elementos como forma e volume, destacando-se as propostas encontradas no Dicionário geológico-geomorfológico (GUERRA, 1972), Enciclopédia Barsa (2004) e Plumb (2005).

Quanto à formação, podem ser do tipo: a) erosiva, formadas durante o entalhamento do curso d'água devido ao potencial erosivo das rochas, b) erosiva devido à existência de descontinuidades, como escarpas de falha e soleiras, c) construtiva (típicas de ambientes 
com rochas calcárias, onde ocorrem os processos de dissolução e deposição da calcita) (BENTO, 2010).

Apesar de tal classificação, Bartorelli (1997), argumenta que, na maioria das vezes, não existe apenas uma explicação para a origem de quedas d'água. De acordo com o autor supracitado, a origem das cachoeiras está associada, inicialmente, com questões de caráter tectono-estrutural e outros fatores como falhas, diáclases, contatos inter derrames, estruturas internas dos derrames, diques etc. terão influência, principalmente, no modelado das cachoeiras (BENTO, 2010).

Percebe-se, a partir da década de 2010 um gradativo enriquecimento na literatura científica sobre quedas d'água, com ênfase, principalmente, na possibilidade de se associar contemplação ao entendimento, indo ao encontro dos ideais do geoturismo (BENTO, 2010; BENTO et al., 2017; DETONI; FONSECA FILHO, 2021; FOLETO; COSTA, 2018; LUERCE, 2015; MELO, 2019; MOCHIUTTI; KURAZ, 2017; OLIVEIRA et al., 2017; OLIVEIRA; SALGADO; LOPES, 2017; SANTOS; MARIANO; NASCIMENTO, 2015; SANTOS, 2016; ZIEMANN; FIGUEIRÓ, 2017; WEBER, 2019).

Quedas d'água podem ser concebidas como elementos da geodiversidade e, assim como a biodiversidade, a totalidade destes elementos compreende o capital natural, ou seja, todos os recursos oferecidos pelo ecossistema terrestre que suportam o sistema econômico vigente. Andrade e Romeiro (2009), consideram que, atualmente, os fluxos de benefícios gerados pelo estoque de capital natural são denominados de serviços de ecossistema, divididos em tangíveis (matéria-prima, como madeira e alimentos, por exemplo) e intangíveis (regulação do clima e beleza cênica, para exemplificar).

A Avaliação Ecossistêmica do Milênio (AEM), programa internacional voltado às necessidades de informações científicas dos tomadores de decisões e do público sobre os impactos que as mudanças nos ecossistemas causam ao bem-estar humano, bem como as respostas a essas mudanças, lançado em junho de 2001, propôs uma taxonomia para esses serviços a partir de quatro categorias, serviços de suporte, aprovisionamento, regulação e culturais (ALCAMO et al., 2003) - (Figura 5). 


\section{SERVICOS DOS ECOSSISTEMAS}

\section{SERVIÇOS} DE SUPORTE

\section{Serviços}

necessários para a produção de todos os outros serviços dos ecossistemas

- Formação do solo

- Ciclos de Nutrientes

- Produção Primária

\section{Serviços de}

ecossistemas

- Comida

- Água Potável

- Combustível

- Fibras

SERVICOS DE

REGULAÇÂO Beneficios processos ecossistemas
Aprovisionamento

Produtos obtidos dos

- Compostos bioquímicos

- Recursos Genéticos através da regulação dos

- Regulação do clima

- Regulação de doenças

- Regulação da água

- Purifícação da água

\section{SERVICOS}

\section{CULTURAIS}

Beneficios não materiais

obtidos dos ecossistemas

- Espirituais e religiosos

- Recreio e turismo

- Estéticos

- Inspiradores

- Educacionais

- Sensação de lugar

- Herança cultural
Determinantes e constituintes do bem estar

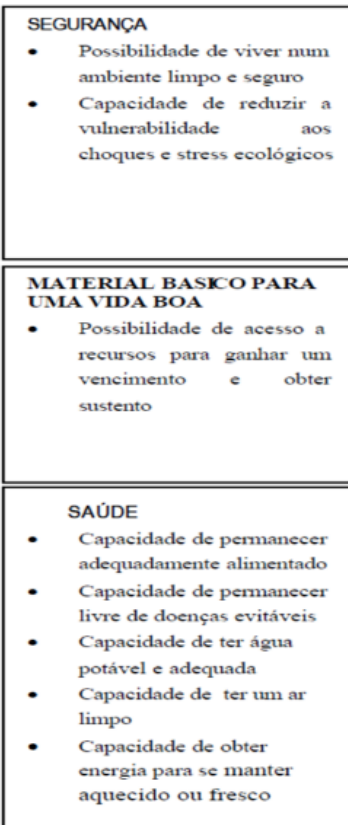

BOA RELAÇOES SOCLAIS - Oportunidade de expressa valores estéticos e de recreio associados aos ecossistemas

- Oportunidade de expressa valores culturais 0 espirituais associados aos ecossistemas

- Oportunidade de observar, estudar e aprender sobre os ecossistemas
LIBERDADES E

ESCOLHA$$
\text { , }
$$

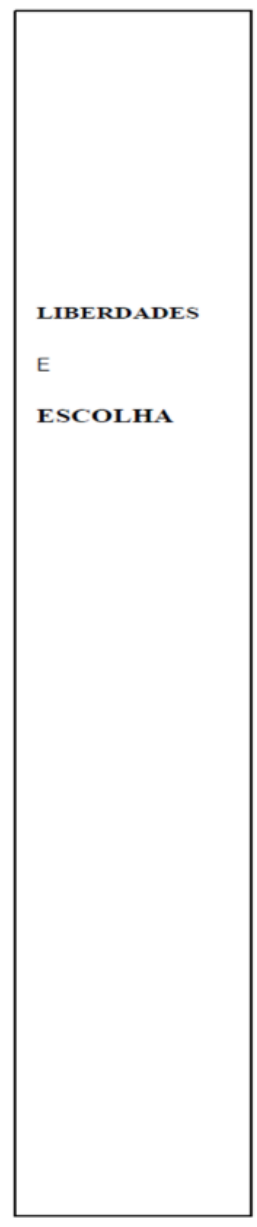

Figura 5 - Serviços de ecossistemas e sua interferência no bem-estar humano Autoria: Adaptado de Alcamo et al., 2003.

É notável o avanço das pesquisas nesta temática, destacando a relevância de se inserir e considerar a geodiversidade nos estudos ambientais; o trabalho de Silva e Mansur (2020), por exemplo, apresenta a ética ecocêntrica como contraponto ao antropocentrismo e avalia sua aplicabilidade nos estudos da geodiversidade. Eles consideram que, ao atribuir valores ecocêntricos à geodiversidade, identificando as relações de seus elementos com todo o ecossistema, é possível valorizar a importância de conservação dos elementos abióticos para o meio ambiente, promovendo uma visão holística sobre a natureza. 
Tem sido recorrente também estudos voltados a identificar os serviços ecossistêmicos da geodiversidade, tanto numa escala genérica (BRILHA et al., 2018; PEREIRA; PEREIRA; BRILHA, 2019; SILVA; MANSUR; NASCIMENTO, 2018), como local, por exemplo, nos trabalhos "A contribuição da Geodiversidade na prestação dos serviços ecossistêmicos do manguezal" (RABELO et al., 2016), "Avaliação qualitativa da geodiversidade como subsídio para a identificação de serviços ecossistêmicos: exemplo do Parque Estadual da Serra do mar, Caraguatatuba-SP" (BALAGUER; GARCIA, RIBEIRO, 2021); "Geodiversidade e serviços ecossistêmicos em trilhas de montanha na travessia Petrópolis - Teresópolis (Parque Nacional da serra dos Órgãos, RJ" - (PESSOA et al., 2018), "Identificação dos serviços ecossistêmicos prestados pela geodiversidade da Bacia de Taubaté - SP: Rifte Continental do Sudeste do Brasil" (REVERTE; GARCIA; BRILHA, 2019); "Serviços ecossistêmicos e geodiversidade em paisagens do Mediterrâneo" (CABEZAS et al., 2021), "Os Serviços Ecossistêmicos em Geossítios do Geopark Araripe (CE), Nordeste do Brasil" (NASCIMENTO; SILVA, MOURA-FÉ, 2020), "Proposta de análise e avaliação dos serviços ecossistêmicos na manutenção da geodiversidade e bem-estar humano: estudo comparativo entre os geoparques Arouca, Portugal e Araripe, Brasil" (COSTA et al., 2019), "Serviços Ecossistêmicos da Geodiversidade: Avaliação e propostas de valoração em locais de interesse geológico do Parque Nacional de Ubajara, Ceará, Brasil" (MEIRA et al., 2020), "Serviços ecossistêmicos e índices de geodiversidade como suporte da geoconservação no Geoparque Seridó" (SILVA, 2018); "Serviços ecossistêmicos da geodiversidade como forma de definição de roteiros no Geoparque Seridó" (SILVA; NASCIMENTO; MANSUR, 2017), entre outros.

Dentro desse contexto, de serviços ecossistêmicos prestados pela geodiversidade, é possível elencar algumas contribuições, diretas ou indiretas, das quedas d'água, algumas bem conhecidas, outras nem tanto, a saber:

i- condições de bem-estar e saúde: estão relacionadas aos benefícios gerados, a maioria, pela inalação de um spray fino e carregado de íons negativos resultante do processo de eletrificação por atrito que ocorre pelo impacto das águas no perfil topográfico rochoso da queda. Esses íons negativos promovem maior oxigenação cerebral (melhora o metabolismo aeróbico) e diminuem os níveis lactato (componente da acidez sanguínea). Há, ainda, melhora do perfil de resposta à serotonina, ajudando a aliviar a depressão e o estresse; além de aumentar a energia durante o dia (GRAFETSTÄTTER et al., 2017). Perez, Alexander e Bailey (2013), acrescentam que esse spray natural é mais efetivo do 
que os artificiais, como os umidificadores, por exemplo, uma vez o seu tempo de permanência aérea iônica é maior e apresenta também maior valor biológico.

ii- inspiração artística: quedas d'água são usadas como fonte de inspiração para as mais variadas expressões de arte, como as Cataratas do Iguaçu (Foz do Iguaçu/PR), por exemplo. Estas constituem, na verdade, um conjunto de 275 quedas, sendo que o salto de maior expressão e beleza cênica é conhecido como Garganta do Diabo, com 90 metros de altura (SALAMUNI et al., 2002). Cerca de seis filmes tiveram essas cataratas como cenário para parte das gravações: 007 - contra o foguete da Morte (1979), Indiana Jones e o Reino da Caverna do Cristal (2008), Tartarugas Ninja - fora das sombras (2016), Paddington 2 (2017), Uma mulher fantástica (2017) e Pantera Negra (2018).

iii- locais sagrados: em algumas religiões afro-brasileiras, como a Umbanda e Candomblé, a natureza é vista como a materialização do divino, sendo não só um lugar para adoração, mas também de onde se retiram os ingredientes para os rituais de adoração. No caso das cachoeiras, elas são usadas como locais para a devoção de Orixás específicos como: Oxum; Oxumarê e lyewá (se a queda formar um arco-íris) e Xangô (PORTUGUEZ, 2015),

iv- conhecimento: se possuírem meios interpretativos, as cachoeiras podem ser aproveitadas do ponto de vista educativo, usando as rochas do perfil da queda como páginas que podem ser lidas e interpretadas. Vários conteúdos do ensino formal podem ser abordados, desde as formas (minerais e rochas) até os processos (ciclo das rochas, tectonismo). Do ponto de vista do tempo geológico, considerando as unidades litoestratigráficas presentes no local, é possível fazer um recorte da história geológica; levando os visitantes a uma viagem no tempo, relacionando processos pretéritos e atuais. Além disso, é interessante suscitar uma visão holística da paisagem, acrescentando informações da biodiversidade, como as plantas que podem ser vistas no perfil da queda, ou mesmo durante a realização das trilhas até chegar na cachoeira (BENTO, 2021a, 2021b).

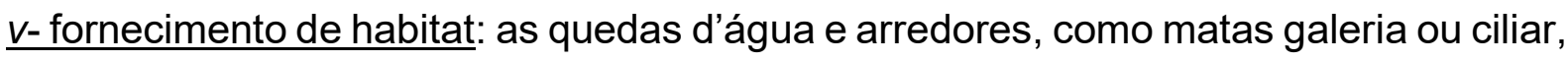
possuem características peculiares e distintas, tais como topográficas, de luz, edáficas e de umidade (durante todo o ano independente da estação), funcionando como refúgio para muitas espécies sensíveis à dessecação, principalmente as briófitas (FERNANDES; ATHAYDE-FILHO; PERALTA, 2021; OLIVEIRA FILHO, 1989).

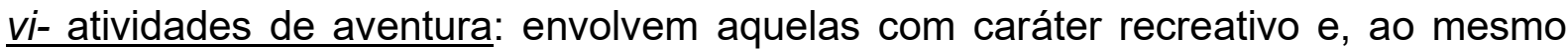
tempo, que apresentem elementos de risco durante a prática. Em cachoeiras, as mais 
comuns são as caminhadas por meio de trilhas (guiadas ou autoguiadas) e o banho nas piscinas naturais. Outras, não tão comuns, são o cachoeirismo, prática de descida de cachoeira, seguindo ou não o curso d'água, usando técnicas verticais. Esta difere-se do rapel por este último ser realizado apenas em ambientes secos. É possível também realizar o canionismo, descida de cursos d'água usualmente em cânions, transpondo qualquer tipo de obstáculo, como quedas d'água, usando diversas técnicas como rapel, flutuação, mergulho e saltos (ABNT, 2007). Em algumas quedas, a prática da tirolesa também pode acontecer, essa consiste no deslizamento do visitante/turista em uma linha aérea que liga dois pontos afastados na horizontal ou em desnível (MELO; AGUIAR, 2016).

Quedas d'água são, definitivamente, muito mais do que espaços para contemplação e realização de atividades recreativas e de aventura. Sua importância perpassa aspectos correlacionados à sua biodiversidade e geodiversidade, influenciando aspectos culturais, educacionais e de bem-estar humano. O desafio reside justamente em popularizar esses outros valores para a sociedade, sendo o geoturismo uma das ferramentas para tal, desde que seja ofertado com meios interpretativos que possibilitem a disseminação desse conhecimento.

\subsection{Minas Gerais e sua quedas: produto ou potencial geoturístico?}

A resposta a esse questionamento está atrelada a dois pontos centrais, um é a necessidade do geoturismo ter elementos abióticos como atrativos turísticos, no caso, as quedas d'água, e outro, a existência de meios interpretativos, para que possam possibilitar o entendimento dos locais visitados, além de outros aspectos/serviços relacionados à atividade turística.

Minas Gerais tem quedas d'água em grande quantidade, em rápida pesquisa em rede social de compartilhamento de fotos, foram encontradas, aproximadamente, 487 publicações de cachoeiras, distribuídas nos quatro domínios morfoestruturais do estado, ou seja, potencial é o que não falta.

A área de estudo está distribuída ao longo de três destes domínios: Salto da Prata Bacia Sedimentar do Paraná; Cachoeira Casca D’anta - Província Tocantins e Cachoeira dos Macacos - entre a Província Mantiqueira e Tocantins (Figura 6). 


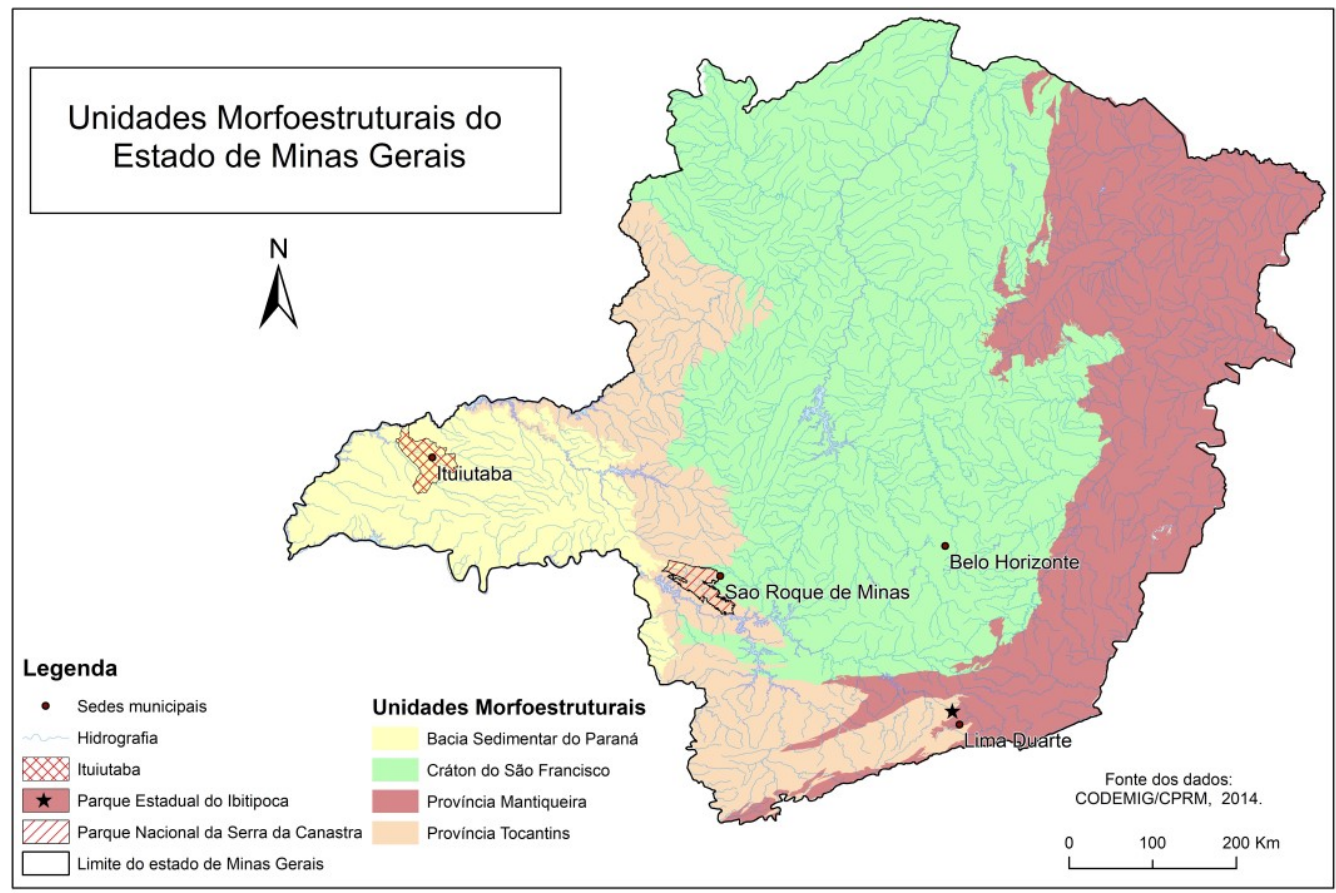

Figura 6 - Localização da área de estudo.

Uma visita a essas quedas, se dotadas de meios interpretativos adequados e direcionados para essa temática (é importante frisar tal necessidade, pois sem isso o entendimento não ocorre), pode oportunizar uma viagem no tempo geológico, marcado por intensas e profundas transformações, comandadas pelos agentes geológicos internos e externos. Como toda viagem, o primeiro passo é colocar na bagagem alguns itens obrigatórios, nesse caso, um rápido apanhado das principais teorias geológicas.

O principal paradigma relacionado a evolução da Terra é a teoria da Tectônica de Placas, é ela que explica toda a dinâmica interna do nosso planeta e de que nem sempre a configuração dos continentes foi como é hoje. Nosso planeta é composto por diferentes camadas com constituição e temperaturas distintas, e o calor interno gera correntes de convecção que faz com que a crosta, parte externa, fina e rígida, se movimente, como numa dança, carregando consigo continentes e oceanos e, até mesmo, propiciando a formação de novos continentes e oceanos.

Esse "baile" das placas, ora se separando ou juntando, formando grandes continentes, recebe o nome de Ciclo dos supercontinentes e, segundo pesquisas, um novo continente está em desenvolvimento e fará parte da paisagem daqui a cerca de 50 a 200 milhões de anos. Através de modelos computacionais, analisando os movimentos lentos dos continentes nas próximas dezenas de milhões de anos, chegou-se à conclusão de que todos os continentes atuais serão colocados juntos em uma única massa de terra ao redor do Polo Norte, formando o Amásia (SMITH, 2012). 
Sabendo que os continentes nem sempre estiveram na mesma localização geográfica atual, não é difícil de crer que o Brasil, hoje afortunadamente localizado no centro de uma placa, a Sul-americana, já bailou por outras áreas, com latitudes e longitudes diferentes das atuais. Existem algumas marcas deixadas nas rochas que sinalizam, por exemplo, para a existência de geleiras no Brasil, muitas refletindo a grande "era do gelo" que ocorreu entre os dois últimos períodos (Carbonífero e Permiano) do Paleozoico. Essas marcas são pavimentos estriados (encontrados em vários estados, como Nordeste, Minas Gerais, Paraná) e litologias típicas desse tipo de ambiente, como diamictito, varvito/ritmito (Itu/SP) e a rocha Moutonnée, esta última apresenta um único exemplar no município de Salto/SP (BICUDO, 2003; CARNEIRO, 2016; PACCOLA; MELO, 2012).

Outras evidências desse "baile" tectônico é a ocorrência de rochas formadas por sedimentos e fósseis marinhos, hoje encontrados em áreas longes da linha da costa, como é o caso do estado de Minas Gerais. Todo esse material estava submerso e, por conta da movimentação convergente das placas tectônicas, resultou na colisão de pequenos continentes, trazendo sedimentos do fundo dos mares para as alturas, formando grandes cinturões orogênicos que serviram como amálgama para um novo super continente: o Gondwana (BENTO; RODRIGUES, 2019; MORAES; SEER, 2015) - (Figura 7).

Os cinturões Mantiqueira e Tocantins, constituintes, respectivamente, das unidades morfoestruturais homônimas, são importantes para a área de estudo, pois formaram a base do que hoje são as serras da Canastra e do Ibitipoca, muito similiar à outras cadeias, como serra do Mar, Cipó e Mantiqueira (TEIXEIRA; LINSKER, 2007). Como resultam de colisão e soerguimento, esses cinturões correspondem a terrenos de grande complexidade litológica e estrutural. A Serra da Canastra está totalmente inserida no cinturão Tocantins e, de modo geral, os principais tipos de rochas aí encontradas são os quartzitos (puros a micáceos), filitos e calcários. Já a Serra do Ibitipoca encontra-se numa faixa de contato entre os cinturões Mantiqueira e Tocantins, sendo uma área ainda mais complexa e de difícil reconhecimento das unidades litológicas, no geral, predominam quartzitos, xistos e gnaisses (BENTO, 2014; BENTO; NAZAR, 2020; BENTO; RODRIGUES, 2019). 


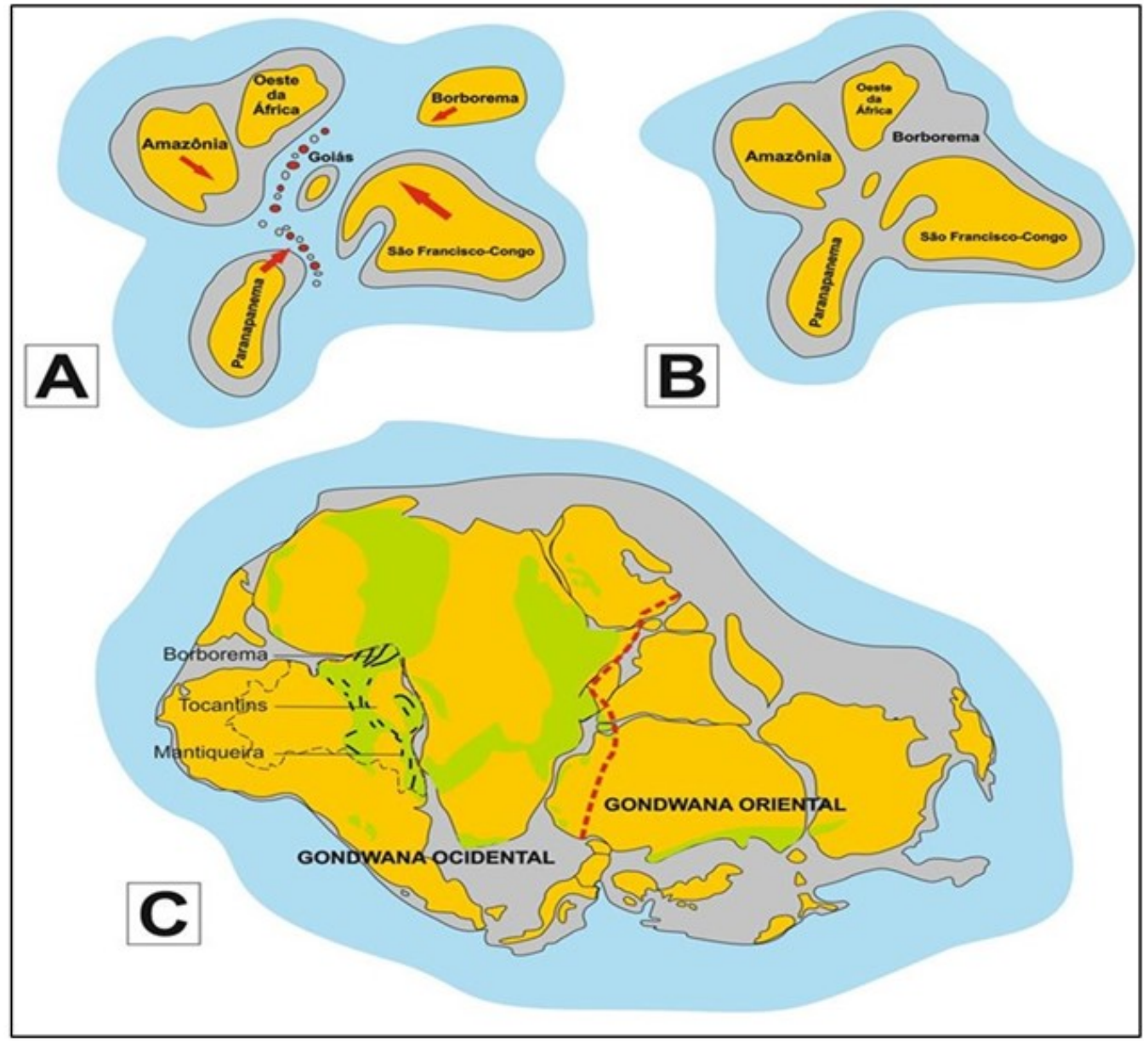

Figura 7 - Bloco diagrama mostrando a formação do supercontinente Gondwana e os cinturões orogênicos. Fonte: Bento; Nazar, 2020.

Mas a história continua, o tempo geológico passa e o grande Gondwana, impelido pelas correntes de convecção, experimenta nova situação, sua separação no período Triássico. Da quebra do que é hoje o continente africano e a América do Sul (partes do Gondwana Ocidental), culminou eventos de magmatismo e geração de feições, mas os de maior significado para a área de estudo são os derrames de basalto e a formação do Oceano Atlântico. Esse magmatismo na forma de derrames influencia nas características do basalto, o qual apresenta texturas distintas de acordo com a posição ocupada. No geral, a base dos derrames é menos espessa, composta por basalto de cor preta e vítrea. $\mathrm{O}$ interior, mais espesso (entre 30 a 40 metros), é formado predominantemente por basalto do tipo colunar. Já o topo, devido ao contato direto com a atmosfera e resfriamento mais rápido, tende a ser formado por basalto vesicular ou amigdaloidal (BENTO, 2018).

Ao mesmo tempo em que ocorre a movimentação das placas tectônicas, reconfigurando todo o formato dos continentes, há a atuação dos agentes geológicos externos, num lento e contínuo trabalho de esculpir e erodir a superfície terrestre. As grandes serras que encontramos hoje em Minas Gerais podem ser consideradas relevos 
residuais, pois são o que sobrou dos cinturões orogênicos expostos às intempéries. A Serra da Canastra se destaca topograficamente por conta dos seus quartzitos que são mais resistentes do que as rochas encontradas no seu entorno. Processo similar ocorre na Serra do Ibitipoca, onde os quartzitos também sustentam as partes mais elevadas da serra (BENTO, 2014; BENTO; NAZAR, 2020; BENTO; NAZAR, 2019).

Salutar esclarecer que após as manifestações de magmatismo, a porção meridional da placa-sul americana veio a sofrer um processo de subsidência termal, resultando no desenvolvimento de muitas bacias interiores, bem como na reativação e geração de fraturas, influenciando na rede de drenagem, formando cânions e cachoeiras. Além disso, desde então, todo o território mineiro vem passando por um processo de erosão que permanece até os dias atuais, ou seja, a história não terminou, o planeta Terra é dinâmico e a atuação dos agentes geológicos, internos e externos, não para (Figura 8).

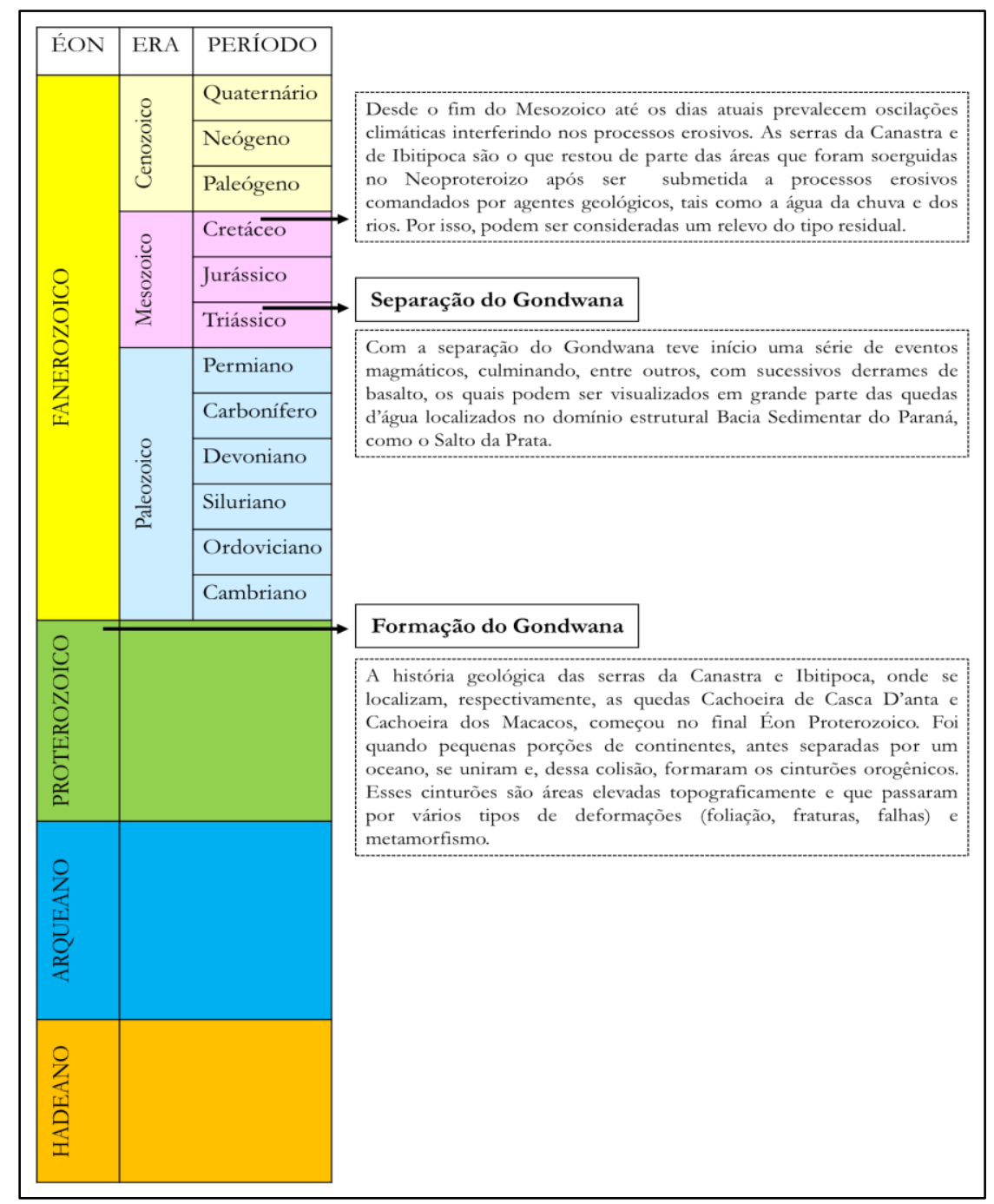

Figura 8 - Escala do tempo geológico com principais acontecimentos na área de estudo.

Fonte: Adaptado de Bento; Nazar, 2020. 
Essa dinamicidade, típica do planeta Terra, hoje acrescida da ação geológica do homem, configura e reconfigura constantemente as paisagens, sendo de suma importância aproveitar espaços como as quedas d'água, que já chamam a atenção da sociedade pela sua beleza, e agregar valor educativo que faça com que as pessoas tenham noção da história do planeta e a do próprio ser humano.

As quedas da área de estudo estão todas estão localizadas em unidades de conservação do tipo integral, ou seja, em que são permitidas apenas o uso indireto dos recursos naturais, sendo a realização de pesquisas científicas e do turismo algumas de suas funções socioculturais (VASCONCELOS, 1998).

Bento e Rodrigues (2013) argumentam que, referente à visitação nesses espaços protegidos, o geoturismo emerge como uma potencialidade, podendo contribuir em três aspectos, a saber: a) econômico (amplia o tempo de permanência no local, se conjugado com outros segmentos), b) educativo (promoção do conhecimento dos aspectos abióticos da natureza) e c) ambiental (valorização e divulgação da geodiversidade, contribuindo com a geoconservação).

Será que o fato destas quedas estarem localizadas em unidades de conservação é garantia para a existência de provisão adequada para o recebimento dos visitantes/turistas e, principalmente, desenvolvimento de programas de educação e interpretação ambientais que não trabalhem apenas a biodiversidade?

O Salto da Prata está localizado no município de Ituiutaba/MG e faz parte do Refúgio de Vida Silvestre Estadual dos Rios Tijuco e da Prata. Este foi criado em 22 de março de 2011 através do Decreto 45.568/2011, com o objetivo de garantir a manutenção e reprodução de espécies de animais ameaçados de extinção (VIEGAS, 2020). Essa unidade de conservação ainda não tem plano de manejo e o Salto da Prata apresenta elevados índices de visitação, comprometendo a qualidade ambiental da área e subutilizando-o do ponto de vista da promoção da educação e interpretação ambiental, um dos objetivos do geoturismo. Viegas (2020), no trabalho "GEOLOGIA NA PALMA DA MÃO: Uma proposta de valorização de divulgação para o Salto da Prata, Ituiutaba-MG", fez a proposição de um aplicativo para celular que reuniu informações sobre os aspectos geológicos para esse salto, podendo ser considerado uma ferramenta de interpretação ambiental a ser, futuramente, usado pelos gestores da unidade.

Já a Cachoeira de Casca D'anta é uma das várias quedas existentes no PARNA Serra da Canastra, localizada no sudeste de MG e criado, principalmente, para proteger nascentes do rio São Francisco. Foi instituído em 3 de abril de 1972, pelo Decreto nº 70.355. 
Segundo Bento e Rodrigues (2019), cerca de $83 \%$ do conhecimento gerado está relacionado com a biodiversidade, mas percebe-se um avanço de pesquisas referentes a geodiversidade e potencial geoturístico do parque. Inclusive, a própria gestão tem se mostrado receptiva e em 2018 ofertou um curso para condutores de turismo, incluindo na pauta a geodiversidade e geoturismo. Bento e Nazar (2020) propuseram um painel interpretativo para a Cachoeira de Casca D'anta, tendo por objetivo geral a interpretação da origem dessa queda, a partir da visualização e correlação com alguns elementos, como falha e rochas, e os processos ao longo do tempo geológico. Relevante destacar que sua confecção e disposição é responsabilidade do ICMBio, instituição gestora das unidades federais.

E, por fim, a Cachoeira dos Macacos é também uma das quedas localizadas no PEI, criado no ano de 1973 pela Lei estadual 6.126, de 4 de julho de 1973. Esse parque conta com um centro de visitantes dotado com uma diversidade de meios interpretativos, os quais abordam não só a biodiversidade como a geodiversidade. A única ressalva é que essa interpretação está restrita ao centro e nem todos os visitantes passam pelo mesmo, suscitando a necessidade de ampliá-la para outros pontos do parque. Nesse sentido, sabendo-se da diversidade de atrativos desse parque, como cavernas, praias fluviais, cachoeiras e mirantes, a colocação de painéis interpretativos, ao menos em um tipo de cada categoria temática, já preencheria uma lacuna do ponto de vista da informação e cumpriria parte da função sociocultural da unidade, "[...] possibilitando a sensibilização dos visitantes e fazendo com a geodiversidade seja de fato a protagonista, e não coadjuvante nos programas de Educação e Interpretação ambientais" (BENTO, 2021).

O fluxograma a seguir reúne algumas possibilidades educativas associadas à essas três quedas, apontando para as formas e processos relacionados a geodiversidade, atrativo principal do geoturismo. Buscou-se fazer uma sequência didática a partir de toda a história geológica que foi contada e as múltiplas possibilidades de interpretação. Trata-se de uma abordagem reducionista, uma vez que é possível (e deve ocorrer) a incorporação de outros elementos da paisagem, como o solo, relevo, plantas, animais, bem como aspectos relacionados às comunidades que vivem nas proximidades, propiciando uma visão integrada, holística e realista. Essa visão integrada do meio ambiente por inteiro, com planta, bicho, rocha, solo, relevo, gente, entre outros, se relacionando e impactando, positivamente ou não, mediante implantação de meios interpretativos variados e em pontos diversos dos parques, pode ser um caminho para uma nova forma de relacionamento com a natureza. Na verdade, talvez seja um pequeno passo em busca da tão sonhada 
Caderno de Geografia (2022) v.32, n.68

ISSN 2318-2962

DOI 10.5752/p.2318-2962.2022v32n.68p.22

sustentabilidade, a qual deve estar atrelada a outras premissas/conceitos relevantes, como a geoética e a geoconservação; todos estes sendo trabalhados de forma conjunta e contínua, como numa engrenagem. 


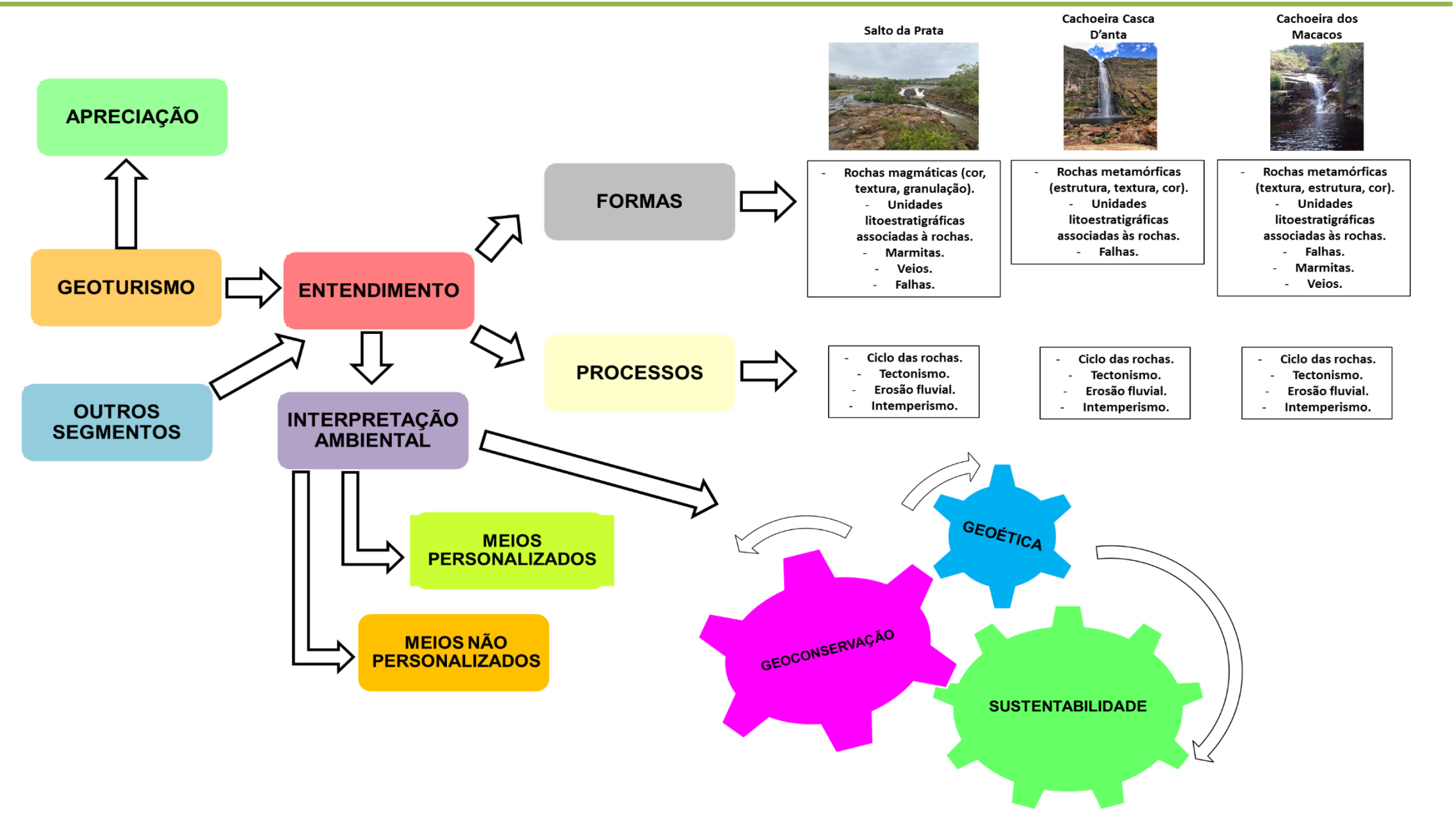

Figura 9 - Fluxograma com as principais inter-relações entre o geoturismo e a área de estudo . 


\section{ALGUMAS CONSIDERAÇÕES}

Este trabalho buscou refletir sobre alguns conceitos básicos como geoturismo e a diferença entre produto e potencial turístico, de forma a subsidiar o objetivo central, analisar o potencial geoturístico de três quedas d'água localizadas em unidades de conservação, de modo a possibilitar o acréscimo de um novo valor (científico) e uso (educativo).

O Geoturismo, independente se é um segmento turístico ou não, é uma prática que vem crescendo em todo o mundo, sendo a criação dos Geoparques uma das suas molas propulsoras. Para ser concebido como produto turístico, precisa muito mais do que ter rica e bela geodiversidade, pois um dos seus objetivos é valorizar e disseminar essa nova temática e, para isso, demanda minimamente de meios interpretativos. Além disso, é uma atividade econômica que, tal como as demais, precisa ser planejada de modo a se minimizar os impactos negativos, bem como ter infraestrutura e serviços para ofertar aos compradores dos produtos, no caso, os turistas.

Pelo exposto infere-se, portanto, que Minas Gerais tem um rico potencial geoturístico na figura das suas quedas d'água, um dos elementos da Geodiversidade e, portanto, atrativo desse segmento. As três quedas analisadas retratam uma pequena parte de toda a beleza, diversidade e riqueza associadas a esse tipo de geopatrimônio do estado de Minas Gerais e seus valores não ficam restritos apenas ao aspecto estético. Muitos são os benefícios e valores associados, os quais precisam ser popularizados de modo a contribuir com a diversificação dos seus usos, principalmente, o didático.

Das quedas analisadas, apenas a Cachoeira dos Macacos pode ser considerada um produto (geo)turístico, uma vez que apresenta todos os elementos para tal; a única ressalva é que haja uma ampliação dos meios interpretativos para as áreas abertas, como na queda em questão, já que nem todos os turistas passam pelo Centro de Visitantes, local onde se concentra toda a interpretação ambiental do parque.

Quanto às outras quedas, a que se encontra numa situação mais problemática é o Salto da Prata, pois o refúgio ainda não conta com plano de manejo. Apesar disso, já existem algumas pesquisas que podem contribuir como os futuros programas de educação e interpretação ambientais da unidade, como é o caso do aplicativo criado por um graduado em Geografia.

A Cachoeira de Casca D'anta está localizada numa unidade de conservação federal, conta com um centro de visitantes, mas há predomínio do conhecimento da biodiversidade. Além disso, não há nenhum meio interpretativo em outros pontos do parque, sinalizando para a sua subutilização do ponto de vista do conhecimento. Entretanto, já houve a 
proposição de um painel interpretativo para essa queda, cabe agora aos gestores transformar a teoria em prática.

Por fim, espera-se que esse trabalho possa subsidiar outras pesquisas, revelando os outros tantos valores e serviços ecossistêmicos que as quedas d'água prestam. E, principalmente, que possa chegar até aos gestores dessas unidades de conservação e servir como uma base para o desenvolvimento de programas de educação e interpretação ambientais que não desprezem a geodiversidade.

Tal concepção equivocada e dicotomizada do meio ambiente, difundida ainda nos dias de hoje, bate de frente com os princípios da geoética, os quais buscam dotar os cidadãos de conhecimentos, competências, comportamentos e valores essenciais, de maneira a participarem ativamente e com responsabilidade na sociedade (RIBEIRO; TRINDADE; VASCONCELOS, 2020). Tais premissas são relevantes, pois o conhecimento da geodiversidade

[...] is essential to support sustainable environmental planning, management and land-use policies. Crucial aspects regarding society's quality of life, such as the maintenance of ecosystems and associated goods and services, sustainable use of resources and prevention of natural disasters, depend intrinsically on the degree of interaction between bio- and geodiversity and respect for geological processes (GARCIA et al., 2021, p. 203).

Conclui-se que o geoturismo, se bem planejado, dotado de meios interpretativos e desenvolvido respeitando as premissas da geoética, pode contribuir com o processo de geoconservação, trazendo benefícios diversos, dentre outros, favorecer a concepção de um meio ambiente como ele verdadeiramente é, por inteiro, com biodiversidade e geodiversidade, devendo ser conhecido e protegido pelos seus valores e serviços que presta a sociedade, não só a atual, mas também para as gerações futuras.

\section{REFERÊNCIAS}

ABNT. NBR 15500: turismo de aventura - terminologia. Rio de Janeiro, 2007.

ALCAMO, J.; ASJ, N. J.; BUTLER, C. D.; CALLICOTT, J. B.; CAPISTRANO, D. B.; CARPENTER, S. R.; CASTILLA, J. C.; CHAMBERS, R.; CHOPRA, K.; DAILY, G. C.; DASGUPTA, P.; GROOT, R.; DIETZ, T.; KUMAR, A.; GADGIL, M. Ecossistema e bemestar humano: Estrutura para uma avaliação. World Resources Institute. 2003. Disponível em: https://www.millenniumassessment.org/documents/document.63.aspx.pdf. Acesso em: 10 fev. 2021.

ANDRADE, D. C.; ROMEIRO, A. R. Capital natural, serviços ecossistêmicos e sistema econômico: rumo a uma "Economia dos ecossistemas". Texto para discussão, Campinas, n. 159, p. 1-23, 2009. 
BALAGUER, L. P.; GUARCIA, M. G. M.; RIBEIRO, L. M. A. L. Avaliação qualitativa da geodiversidade Como subsídio para a identificação de serviços Ecossistêmicos: exemplo do Parque Estadual da Serra Do mar, Caraguatatuba-SP. In: CONGRESSO BRASILEIRO DE GEOLOGIA, 50., 2021, Brasília. Anais... Brasília: SBG, 2021. p. 26-29.

BARTORELLI, A. As grandes cachoeiras da Bacia do Paraná e sua relação com alinhamentos tectônicos. 1997. 190 f. Tese (Doutorado em Geologia) - Instituto de Geociências e Ciências Exatas, Universidade Estadual Paulista, Rio Claro, 1997.

BENTO, L. C. M. Cachoeira da Casca D'anta, PARNA Serra da Canastra (MG). Boletim AGeoBR, set. 2021a, p. 5.

BENTO, L. C. M. Cachoeiras: páginas de evolução do planeta Terra? Leia cientistas, Uberlândia, 8 jun. 2021b. Disponível em: https://comunica.ufu.br/noticia/2021/06/cachoeiras-paginas-de-evolucao-do-planeta-terra. Acesso em: 6 out. 2021.

BENTO, L. C. M. Potencial geoturístico das quedas d'água de Indianópolis. 2010. 150 f. Dissertação (Mestrado em Geografia) - Instituto de Geografia, Universidade Federal de Uberlândia, Uberlândia, 2010.

BENTO, L. C. M. Parque Estadual do Ibitipoca/MG: potencial geoturístico e proposta de leitura do seu geopatrimônio por meio da interpretação ambiental. 2014. 185 f. Tese (Doutorado em Geografia) - Instituto de Geografia, Universidade Federal de Uberlândia, Uberlândia, 2014.

BENTO, L. C. M. Geodiversidade: de coadjuvante à protagonista, uma reflexão a partir dos programas de educação e interpretação ambientais do Parque Estadual do lbitipoca (PEI). In: RAMOS, F. S. N.; SILVA, J. F. S.; SILVA, E. V.; BANDEIRA, A. M.; MARTINS, J. C. V.; LIMA, I. B. O. V. (Org.). Educação ambiental, ecopedagogia e cartografia social. Tomo 5. São Luiz: EDUFMA, 2021. cap. 11, p. 108-117.

BENTO, L. C. M. Alguns apontamentos sobre os aspectos geológicos da Mesorregião do Triângulo e Alto Paranaíba (Minas Gerais). In: PORTUGUEZ, A. P.; SOBRINHO, L. A. (Org.). Inquietações geográficas: natureza, sociedade e turismo no Brasil contemporâneo. Ituiutaba: Barlavento, 2018. p. 63-89.

BENTO, L. C. M.; NAZAR, T. I. S. M. Parque Nacional Serra da Canastra (Minas Gerais Brasil): proposta de painel interpretativo. Caderno de Geografia, Belo Horizonte, v. 30, ed. Especial 1, p. 112-135, 2020.

BENTO, L. C. M.; RODRIGUES, S. C. Aspectos geológicos e geomorfológicos da Cachoeira de Casca D'anta (Parque Nacional da Serra da Canastra - Minas Gerais, Brasil): primeiros passos para o seu aproveitamento geoturístico. Revista Ibero-Afro-Americana de Geografia Física e Ambiente, v. 1, n. 2, p. 43-60, 2019.

BENTO, L. C. M.; RODRIGUES, S. C. Geoturismo em unidades de conservação: uma nova tendência ou uma necessidade real? - estado da arte. Revista do Departamento de Geografia, v. 25, p. 77-97, 2013. 
BENTO, L. C. M.; RODRIGUES, S. C. Seleção de geossítios para uso turístico no Parque Estadual do lbitipoca/MG (PEI): uma proposta a partir de metodologias de avaliação numérica. Investigaciones Geográficas, n. 85, p. 33-46, 2014.

BENTO, L. C. M.; FARIAS, M. F.; NASCIMENTO, M. A. L. Geoturismo: um segmento turístico? Revista TURISMO: Estudos e Práticas, v. 9, n. 1, p. 1-23, 2020.

BENTO, L. C. M.; BRITO, A. L.; SEVERINO, E. A. S.; JUNIOR, I. B. S.; LISBOA, ANDRADE, R.; V. C. S. Metodologias de avaliação do patrimônio Geomorfológico com vistas ao seu aproveitamento geoturístico - um estudo aplicado às quedas d'água do município de Indianópolis (Minas Gerais - Brasil). Rev. Bras. Geomorfol., São Paulo, v. 18, n. 3, p. 657670, 2017.

BICUDO, F. As geleiras viraram sertão. Revista FAPESP, São Paulo, v. 87, p. 40-43, 2003.

BRILHA, J. Patrimônio geológico e geoconservação - a conservação da natureza na sua vertente geológica. Braga: Palimage, 2005. 94P.

BRILHA, J.; GRAY, M.; PEREIRA, D. I.; PEREIRA, P. Geodiversity - an integrative review as a contribution to the sustainaible management of the whole of nature. Environ Sci. Pol., v. 86, p. $19-28,2018$.

CABEZA, J.; GALLARDO, J. M.; GÓMEZ, J. M. N.; FERNÁNDEZ-POZO, L.; CASTANHO, R. A. Serviços ecossistêmicos e geodiversidade em paisagens do Mediterrâneo. In: SOUZA-FERNANDES, L. C. de; ARAGÃO, A.; SÁ, A. A. (Org.). Novos rumos do direito ambiental - um olhar para a geodiversidade. Campinas: Ed. da Unicamp, 2021. cap. 15, p. 349-366.

CARNEIRO, C. D. R. Glaciação antiga no Brasil: parques geológicos do Varvito e da Rochas Montonnée nos municípios de Itu e Salto, SP. TerraeDidática, v. 12, n. 3, p. 209219, 2016.

COSTA, S. F.; CUNHA, L.; SANTOS, N.; NASCIMENTO, M. Proposta de análise e avaliação dos serviços ecossistêmicos na manutenção da geodiversidade e bem-estar humano: estudo comparativo entre os Geoparques Arouca, Portugal e Araripe, Brasil. In: ENCONTRO LUSO-BRASILEIRO DE PATRIMÔNIO GEOMORFOLÓGICO E GEOCONSERVAÇÃO, 3., 2019, Guimarães. Anais... Guimarães, 2019. p. 241-251.

COUTINHO, A. C. A.; URANO, D. G.; MATE, A. J.; NASCIMENTO, M. A. L. Turismo e geoturismo: uma problemática conceitual. Rosa dos Ventos - Turismo e Hospitalidade, v. 11, n. 4, p. 754-772, 2019.

DETONI, H.; FONSECA FILHO, R. E. Potencial do Parque Municipal das Andorinhas, Ouro Preto (MG) para o geoturismo. Turismo- visão e ação, v. 23, n. 2, p. 350-375, 2021.

DOWLING, R. K. Geotourism's global growth. Geoheritage, v. 3., p. 1-13, 2011.

FERNANDES, L. R.; ATHAYDE-FILHO, F. P.; PERALTA, D. F. Cachoeiras como refúgio para briófitas no cerrado brasileiro. Research, Society and Development, v. 10, n. 11, p. 1-19. 2021. 
FIORAVANTI, C. Lugares com rochas relevantes. Revista Fapesp, São Paulo, n. 308, p. 60-63, 2021.

FOLETO, E.; COSTA, F. Potencialidades e limites para delimitação de hidrosítios no contexto da geoconservação. In: VIEIRA, A.; FIGUEIRÓ, A.; CUNHA, L.; STEINKE, V. (Eds.). Geopatrimónio, geoconhecimento, geoconservação e geoturismo: experiências em Portugal e na América Latina. Ebook. Guimarães: CEGOT, 2018. p. 5366.

GARCIA, M. G.; NASCIMENTO, M. A. L.; MANSUR, K. L.; PEREIRA, R. G. F. A. Geoconservation strategies framework in Brazil: Current status from the analysis of representative case studies. Environmental Science and Policy, n. 128, p. 194-207, 2022.

GRAFETSTÄTTER, C.; GAISBERGER, M.; PROSSEGGER, J.; RITTER, M.; KOLARZ, P.; PICHLER, C.; THALHAMER, J.; HARTL, A. Does waterfall aerosol influence mucosal immunity and chronic stress? A randomized controlled clinical trial. Journal of Physiological Anthropoloy, v. 36, n. 10, p. 1-21, 2017.

GUERRA, A. T. Dicionário Geológico-Geomorfológico. 4. ed. Rio de Janeiro: Instituto Brasileiro de Geografia, 1972. 439p.

MEIRA, S. A.; NASCIMENTO, M. A. L.; SILVA, E. V.; ARNEDO, M. T. E. Serviços ecossistêmicos da geodiversidade: avaliação e propostas de valoração em locais de interesse geológico do Parque Nacional de Ubajara, Ceará, Brasil. Caderno de Geografia, v. 30, n. 62, p. 788-816, 2020.

MELO, F. C. As cascatas da Ferida Má e do Poço Negro: contributo para a caracterização e valorização dos Monumentos Naturais Locais Geoparque Litoral Viana do Castelo. 2019. 96 f. Dissertação (Mestrado em Geociências) - Escola de Ciências, Universidade do Minho, Braga, 2019.

MELO, S. M. C.; AGUIAR, E. P. S. Turismo de aventura em Taquaraçu - TO: atividades e riscos. Turismo - visão e ação, v. 18, n. 2, p. 281-299, 2016.

MOCHIUTTI, N. F. B.; KURAZ, U. R. O valor didático das cachoeiras de Prudentópolis (PR). Ra'eGa, v. 40, p. 79-93, 2017.

MORAES, L. C. de; SEER, H. J. Serra da Canastra: de mar a montanha. Ciência Hoje, v. 55, n. 328, p. 25-29, 2015.

NASCIMENTO, M. A.; RUCHKYS, U. A.; MANTESSO NETO, V. Geodiversidade, geoconservação e geoturismo - trinômio importante para a proteção do patrimônio geológico. São Paulo: SBG, 2008. 84p.

NASCIMENTO, M. A. L.; SILVA, M. L. N.; MOURA-FÉ, M. M. Os Serviços Ecossistêmicos em Geossítios do Geopark Araripe (CE), Nordeste do Brasil. Anuário do Instituto de Geociências, Rio de Janeiro, v. 43, n. 4, p. 119-132, 2020.

LUERCE, T. D. Geoturismo na bacia hidrográfica do Rio Rolante/RS: um estudo acerca das Quedas d'água. 2015. 180 f. Dissertação (Mestrado) - Instituto de Geociências, Universidade Federal do Rio Grande do Sul, Porto Alegre, 2015. 
OLIVEIRA FILHO, A. T. Composição florística e estrutura comunitária na floresta de galeria do córrego Paciência, Cuiabá (MT). Acta bot. Bras., v. 3, n. 1, p. 91-112, 1989

OliVEIRA, C. K. R.; SALGADO, A. A. R.; LOPES, F. W. A. Proposta de Classificação de Relevância de Quedas D'água como Subsídio à Conservação do Patrimônio Natural. Revista Brasileira de Geomorfologia, v. 18, p. 465-481, 2017.

OLIVEIRA, C. K. R.; SALGADO, A. A. R.; LOPES, F. W. A.; P. T. A. Geoconservação e patrimônio geológico: uma discussão sobre a relevância das quedas d'água. Caderno de geografia, Belo Horizonte, v. 27, ed. Especial, p. 201-223, 2017.

PACCOLA, M. A. R.; MELLO, M. S. de. Influência geoambiental em mudanças de atitudes e econômicas na Colônia Witmarsum, Paraná. Boletim geográfico, Maringá, v. 30, n. 1, p. 101-120, 2012

PEREIRA, D. I.; PEREIRA, P.; BRILHA, J. A geodiversidade no contexto dos serviços dos ecossistemas. In: RAMOS-PEREIRA, A.; LEAL, M.; BERGONSE, R.; TRINDADE, J.; REIS, E. (Eds.). Água e território - um tributo a Catarina Ramos. Lisboa: CEG, 2019, p. 251-268.

PEREZ, V.; ALEXANDER, D. D.; BAILEY, W. H. Air ions and mood outcomes: a review and meta-analysis. BMC Psychiatry, v. 13, n. 29, p. 13-29, 2013.

PESSOA, F.; ARAÚJO, J.; SEOANE, J. C.; CAMBRA, M. F.; GIRALDO, S.; MARTINS, G.; MANSUR, K.; PEIXOTO, M. N. Geodiversidade e serviços ecossistêmicos Em trilhas de montanha na travessia Petrópolis - Teresópolis (Parque Nacional da Serra dos Órgãos, RJ). In: SIMPÓSIO NACIONAL DE GEOMORFOLOGIA, 12., 2018, Crato. Anais... Crato: UGB, 2018. p. 1-6.

PORTUGUEZ, A. P. Espaço e cultura na religiosidade afrobrasileira. Ituiutaba: Barlavento, 2015. 139p.

PLUMB, G. Waterfall Lover's Guide: Pacific Northwest. 4. ed. Mountaineers Books. 2005. 349p.

QUEDA d'água. In: Enciclopédia Barsa. São Paulo: Barsa Planeta Internacional, 2004, v. 12. $144 p$.

RABELO, T. O.; SANTOS, N. M.; COSTA, D. F. S.; NASCIMENTO, M. A. L.; LIMA, Z. M. C. A contribuição da geodiversidade na prestação dos serviços ecossistêmicos do manguezal. REGNE, v. 4, n. esp., p. 281-297, 2018.

REVERTE, F. C.; GARCIA, M. G.; BRILHA, J. Identificação dos serviços ecossistêmicos prestados pela geodiversidade da Bacia de Taubaté-SP: Rifte Continental do Sudeste do Brasil. In: SIMPÓSIO BRASILEIRO DE PATRIMÔNIO GEOLÓGICO, 5., 2019, Crato. Anais... Crato, 2019.

REYNARD, E. Scientific research and tourist promotion of geomorphologica heritage. Geogr. Fis. Dinam. Quat., v. 31, p. 225-230, 2008. 
RIBEIRO, T.; TRINDADE, R.; VASCONCELOS, C. Educar e Comunicar em Geociências através da Ciência Cidadã: um projeto de investigação potenciador de uma visão Geoética. Geonovas, v. 33, n. 1-2, p. 55-62, 2020.

RUCHKYS, U. A.; MANSUR, K.; BENTO, L. M. A Historical and Statistical Analysis of the Brazilian Academic Production, on Master's and PhD Level, on the Following Subjects: Geodiversity, Geological Heritage, Geotourism, Geoconservation and Geoparks. Anuário do Instituto de Geociências, v. 40, n. 1, p. 180-190, 2017.

SALAMUNI, R.; ROCHA, L. A.; ROCHA, A. L.; SALAMUNI, E. Parque Nacional do Iguaçu, PR - Cataratas de fama mundial. In: SCHOBBENHAUS, C.; CAMPOS, D. A.; QUEIROZ, E. T.; WINGE, M.; BERBERT-BORN, M. (Eds.). Sítios Geológicos e Paleontológicos do Brasil. Brasília: DNPM/CPRM, 2002. p. 313-321.

SANTOS, F. M. dos. Caracterização geoambiental das cachoeiras do município de Guarulhos/SP: uma avaliação do seu potencial geoturístico. 2015. 147 f. Dissertação (Mestrado em Análise Geoambiental) - Universidade de Guarulhos, Guarulhos, 2015.

SANTOS, E. M.; MARIANO, G.; NASCIMENTO, M. A. L. Geotouristic potential of waterfalls in igneous and metamorphic rocks: the case of the municipality of bonito, Pernambuco, northeast Brazil. Caderno de Geografia, v. 25, n. 43, p. 179-191, 2015.

SILVA, M. L. N. Serviços ecossistêmicos e índices de geodiversidade como suporte da geoconservação no geoparque Seridó. 2018. 177p. Dissertação (Mestrado em Geociências) - Museu Nacional, Rio de Janeiro, 2018.

SILVA, H. V. M.; AQUINO, C. M. S.; AQUINO, R. P. Potencial geoturístico das quedas d'água do município de Novo Santo Antônio - Piauí. In: FALCÃO SOBRINHO, J.; NASCIMENTO, F. R.; CLAUDINOSALES, V. (Orgs.). Geodiversidade: abordagens teóricas e práticas. 1 ed. Sobral/Ceará: Sertão Cult, 2020, p. 125-145.

SILVA, J.; ALVES, G. B.; ROSS, J. L. S.; OLIVEIRA, F. S.; NASCIMENTO, M. A. L.; FELINI, M. G.; MANOSSO, F. C.; PEREIRA, D. I. The Geodiversity of Brazil: Quantification, Distribution, and Implications for Conservation Areas. Geoheritage, v. 13, n. 75, p. 1-21 2021.

SILVA, M. L. N.; MANSUR, K. L. Ecocentrismo e sua aplicabilidade em estudos da geodiversidade. Anuário do Instituto de Geociências, Rio de Janeiro, v. 43, n. 3, p. 415424, 2020.

SILVA, M. L. N.; MANSUR, K. L.; NASCIMENTO, M. A. L. Serviços ecossistêmicos da natureza e sua aplicação nos estudos da geodiversidade: uma revisão. Anuário do Instituto de Geociências, v. 4, n. 2, p. 699-709, 2018.

SILVA, M. L. N.; NASCIMENTO, M. A. L.; MANSUR, K. L. Serviços ecossistêmicos da geodiversidade como forma de definição de roteiros no Geoparque Seridó. In: SIMPÓSIO BRASILEIRO DE PATRIMÔNIO GEOLÓGICO, 4., 2017, Ponta Grossa. Anais... Ponta Grossa, 2017. p. 382-386. 
SILVA, G. B.; NEIVA, R. M. S.; FONSECA FILHO, R. E.; NASCIMENTO, M. A. L. Potencialidades do Geoturismo para a criação de uma nova segmentação turística no Brasil. Revista Turismo em Análise, v. 32, n. 1, p. 1-18, 2021.

SOARES, A. V. Geologia na palma da mão: uma proposta de valorização para o Salto da Prata, Ituiutaba-MG. 2020. 70 f. Monografia (Trabalho de Graduação em Geografia) Universidade Federal de Uberlândia, Ituiutaba, 2020.

SMITH, K. Supercontinente Amásia assumirá posição no Pólo Norte. Nature, 2012. Disponível em: https://www.nature.com/articles/nature.2012.9996. Acesso em: 17 abr. 2021.

TEIXEIRA, W.; LINSKER, R. Itatiaia: sentinela das alturas. 1. ed. São Paulo: Terra Virgem, 2007. 160p.

VASCONCELOS, J. M. O. Avaliação da visitação pública e da eficiência de diferentes tipos de trilhas interpretativas no Parque Estadual do Pico do Marumbi e Reserva Natural Salto Morato - PR. 1998. 151 f. Tese (Doutorado em Ciências Florestais) - Setor de Ciências Agrárias, Universidade Federal do Paraná, Curitiba, 1998.

WEBER, A. Valoração geoturística das quedas d'água do município de Itaara-RS. 2019. 127 f. Dissertação (Mestrado em Geografia) - Departamento de Geociências, Universidade Federal de Santa Maria, Santa Maria, 2019.

ZIEMANN, D. R.; FIGUEIRÓ, A. S. Avaliação do Potencial Geoturístico no Território da Proposta Geoparque Quarta Colônia. Revista do Departamento de Geografia, v. 34, p. 137-149, 2017. 